\title{
POTENSI BATUBARA UNTUK PENGEMBANGAN GASIFIKASI BAWAH PERMUKAAN : STUDI KASUS DESA MACANG SAKTI, PROVINSI SUMATERA SELATAN
}

\author{
Coal Potential for Underground Gasification Case Study : Macang \\ Sakti Village, South Sumatera
}

\author{
ASEP B. PURNAMA ${ }^{1,2)}$, YUDHA S. SUBARNA ${ }^{1)}$, YOGA A. SENDJADJA ${ }^{2)}$, \\ BUDI MULJANA ${ }^{2)}$ dan BINARKO SANTOSO ${ }^{1)}$ \\ 1) Puslitbang Teknologi Mineral dan Batubara \\ Jalan Jenderal Sudirman 623 Bandung 40211 \\ Telp. (022) 6030483, Fax. (022) 6003373 \\ e-mail: asepb@tekmira.esdm.go.id \\ 2) Teknik Geologi, Universitas Padjadjaran \\ Jl. Raya Bandung Sumedang KM 21, Jatinangor 45363 \\ Telp. (022) 7796545, Fax. (022) 7796545
}

\begin{abstract}
ABSTRAK
Batubara yang cocok untuk kegiatan gasifikasi bawah permukaan harus memenuhi persyaratan, antara lain kondisi geologis, ketebalan, kedalaman, kadar air total dan kadar abu. Berdasarkan persyaratan ini, tidak semua batubara dalam bisa dimanfaatkan untuk kegiatan gasifikasi bawah permukaan. Kegiatan eksplorasi batubara perlu dilakukan untuk meminimalisasi risiko geologis dan untuk mengetahui kondisi batubaranya. Berdasarkan hasil permodelan, ditemukan lapisan batubara D dengan kriteria kedalaman 200-300 m, ketebalan $>5 \mathrm{~m}$, kadar total air lembab + kadar abu $<60 \%$, nilai kalor 4.912-6.275 kkal $/ \mathrm{kg}$, reflektansi vitrinit 0,23-0,44 (lignit-subbituminus). Perhitungan sumber daya batubara dengan menggunakan software yang ada dan mengacu pada aturan SNI 5015-2011, menghasilkan sumberdaya tereka 3.316.578 ton, tertunjuk 1.909.560 ton dan terukur 2.479.951 ton.
\end{abstract}

Kata kunci: batubara macang sakti, kualitas, gasifikasi batubara bawah permukaan, perhitungan sumberdaya.

\begin{abstract}
Coal that is suitable for underground gasification must have a certain qualification, among others, geologic condition, thickness, depth, total moisture + ash contents. According to this qualification, not all deep-seated coals can be utilized for underground gasification activity. A coal exploration activity needs to be carried out to minimalize a geologic risk and to know the condition of the coal. Based on the result of the model, coal seam $D$ is suitable for the underground gasification with criteria as follows: depth of 200-300 m, the thickness of $>5 \mathrm{~m}$, total moisture + ash contents of $<60 \%$, the calorific value of 4,912-6,275 $\mathrm{kcal} / \mathrm{kg}$, a vitrinite reflectance of 0.23-0.44 (lignite-sub bituminous). Calculation of the coal resource is conducted by using software and applying SNI 5015-2011, resulting in inferred resource of 3,316,578 tons, indicated resource of $1,909,560$ tons and measured resource of 2,479,951 tons
\end{abstract}

Keywords: Macang Sakti coal, quality, underground coal gasification, resource calculation 


\section{PENDAHULUAN}

Prospek pengembangan eksploitasi batubara di Indonesia masih cukup banyak, dengan sumber daya sekitar 124.796, milyar ton dan cadangan 32.38 milyar ton (Badan Geologi, 2014) yang dapat ditambang secara konvensional hingga mencapai kedalaman $\pm 300 \mathrm{~m}$. Proses penambangan batubara merupakan pekerjaan yang berbahaya dan tidak selalu ekonomis, terutama bila batubara memiliki letak yang terlalu dalam antara 300-1.000 m atau terlalu rendah kualitasnya. Dengan demikian, batubara tersebut tidak bisa ditambang secara ekonomis, sehingga perlu dipikirkan metode penambangan alternatif untuk dapat mengeksploitasi batubara yang berada di kedalaman antara 300-1.000 m. Beberapa penulis seperti Zieleniewski dan Brent (2008), Bhutto dkk. (2013), Kapusta dkk. (2013), Bielowicz and Kasiński (2014), Imran dkk. (2014) memperkirakan bahwa hanya $\pm 16 \%$ dari batubara dunia yang dapat ditambang secara ekonomis. Sisanya sebesar $84 \%$ masih memerlukan pemikiran untuk dapat memanfaatkannya.

Fatimah dkk. (2014) menyatakan bahwa batubara masih ada sampai kedalaman 1.000 $\mathrm{m}$, bahkan potensinya jauh lebih besar dari apa yang dilaporkan saat ini. Potensi batubara dalam (deep seated coal) Indonesia pada kedalaman batubara antara 100-500 m dengan total sumber daya batubara sebesar 41,5 miliar ton diperoleh dari 6 cekungan batubara (Sumatera Selatan, Kutai, Barito, Pasir, Tarakan dan Ombilin). Batubara dalam dapat dimanfaatkan dengan metode metana batubara dan underground coal gasification (UCG).

UCG belum pernah dikaji dan dilakukan di Indonesia, baik teknologinya maupun kecocokan kondisi geologi batubaranya, sehingga belum diketahui kemungkinan pengembangan teknologi ini dapat berlangsung di Indonesia. Batubara yang cocok untuk pengembangan UCG adalah lignit sampai bituminus (Khadse $d k k .$, 2007; Friedmann $d k k ., 2009$; Kreynin, 2012; Bhutto $d k k ., 2013$; (Imran $d k k ., 2014)$. Selain karakteristik batubara, perlu juga dikaji karakteristik kedalaman, ketebalan, kualitas, kondisi struktur dan lapisan penutup batubara (Santoso, 2015). Kondisi karakteristik batubara, antara lain ketebalan minimum, peringkat, kadar abu+ air lembab $<60 \%$, kedalaman antara 200-300 m, rekahan, struktur geologi di sekitar lokasi UCG disarankan sederhana dan kondisi batuan pengapit batubara relatif tidak lulus air. Karakteristik ini perlu dikaji secara komprehensif untuk mengetahui potensi pengembangan UCG di Indonesia.

Untuk dapat memanfaatkan potensi sumber daya batubara yang ada di bawah permukaan, perlu diketahui model geologi batubaranya, yakni dengan melakukan kegiatan eksplorasi pengeboran. Hasil pengeboran ini selanjutnya dimanfaatkan dalam pembuatan permodelan geologis yang merupakan representasi bawah permukaan yang ditampilkan secara digital. Permodelan ini menggunakan data numerik, konfigurasi, korelasi, bentuk dan struktur lapisan batubara.

Pencarian sumber daya batubara yang sesuai dengan kriteria yang cocok untuk UCG dilakukan dengan kriteria kedalaman 200-300 $\mathrm{m}$, ketebalan $>5 \mathrm{~m}$ dan dengan kegiatan kedalaman pengeboran rata-rata $300 \mathrm{~m}$. Permodelan dan perhitungan dilakukan untuk memperkirakan jumlah sumber daya batubara yang bisa diekstraksi dengan metode UCG. Permodelan ini diharapkan menjadi salah satu acuan ke depan dalam eksplorasi batubara untuk pengembangan UCG. Hasil permodelan dapat berubah, apabila di kemudian hari didapatkan data titik bor baru, singkapan baru dan tataan topografi yang berubah (Darmawan, 2012).

Berdasarkan kriteria batubara untuk UCG seperti pada penjelasan di atas, daerah Desa Macang Sakti, Kecamatan Sanga Desa, Kabupaten Musi Banyuasin, Provinsi Sumatera Selatan dipilih untuk kegiatan penelitian dengan luas sekitar 50 ha (Gambar 1). Tujuan kegiatan ini adalah untuk mengetahui permodelan batubara untuk mengembangkan UCG sebagai sumber energi baru.

\section{METODE}

Metode penelitian yang diterapkan dalam kegiatan penelitian ini meliputi:

- Penentuan lokasi titik pengeboran dengan menggunakan alat ukur topografi dan global positioning system.

- Pengeboran eksplorasi batubara untuk mengetahui kedalaman, ketebalan lapisan 
batubara, kondisi stuktur geologi dengan rata-rata kedalaman antara 250-300 m.

- Logging geofisika untuk mengoreksi ke dalaman, ketebalan lapisan batuan, terutama batubara, dan kedalaman pengeboran.

- Permodelan penyebaran lapisan batubara.

- Percontoh batubara diambil dari inti pengeboran.

- Percontoh batubara kemudian dipreparasi, dibungkus, dan diberi kode

\section{Dasar Perhitungan Sumber Daya}

Secara umum semua standar perhitungan memberikan suatu petunjuk untuk penaksiran sumber daya, yaitu berdasarkan jarak (radius) pengaruh dari suatu titik observasi atau pengukuran. Titik observasi adalah suatu lokasi yang diketahui dari singkapan lapisan batubara di permukaan atau di bawah permukaan.
Klasifikasi sumber daya dan cadangan menurut BSN (2011) adalah sebagai berikut:

- Sumber daya tereka, yaitu bagian dari total estimasi sumber daya batubara yang kualitas dan kuantitasnya hanya dapat diperkirakan dengan tingkat kepercayaan yang rendah. Titik informasi yang mungkin didukung oleh data pendukung tidak cukup untuk menentukan kemenerusan lapisan batubara dan/atau kualitasnya. Estimasi kategori kepercayaan ini dapat berubah secara berarti dengan eksplorasi lanjut.

- Sumber daya tertunjuk, yaitu bagian dari total sumber daya batubara yang kualitas dan kuantitasnya hanya dapat diperkirakan dengan tingkat kepercayaan yang masuk akal, didasarkan pada informasi yang didapatkan dari titik-titik pengamatan yang mungkin didukung oleh data pendukung. Titik informasi yang ada cukup untuk menginterpretasikan kemenerusan lapisan batubara dan/atau kualitasnya.

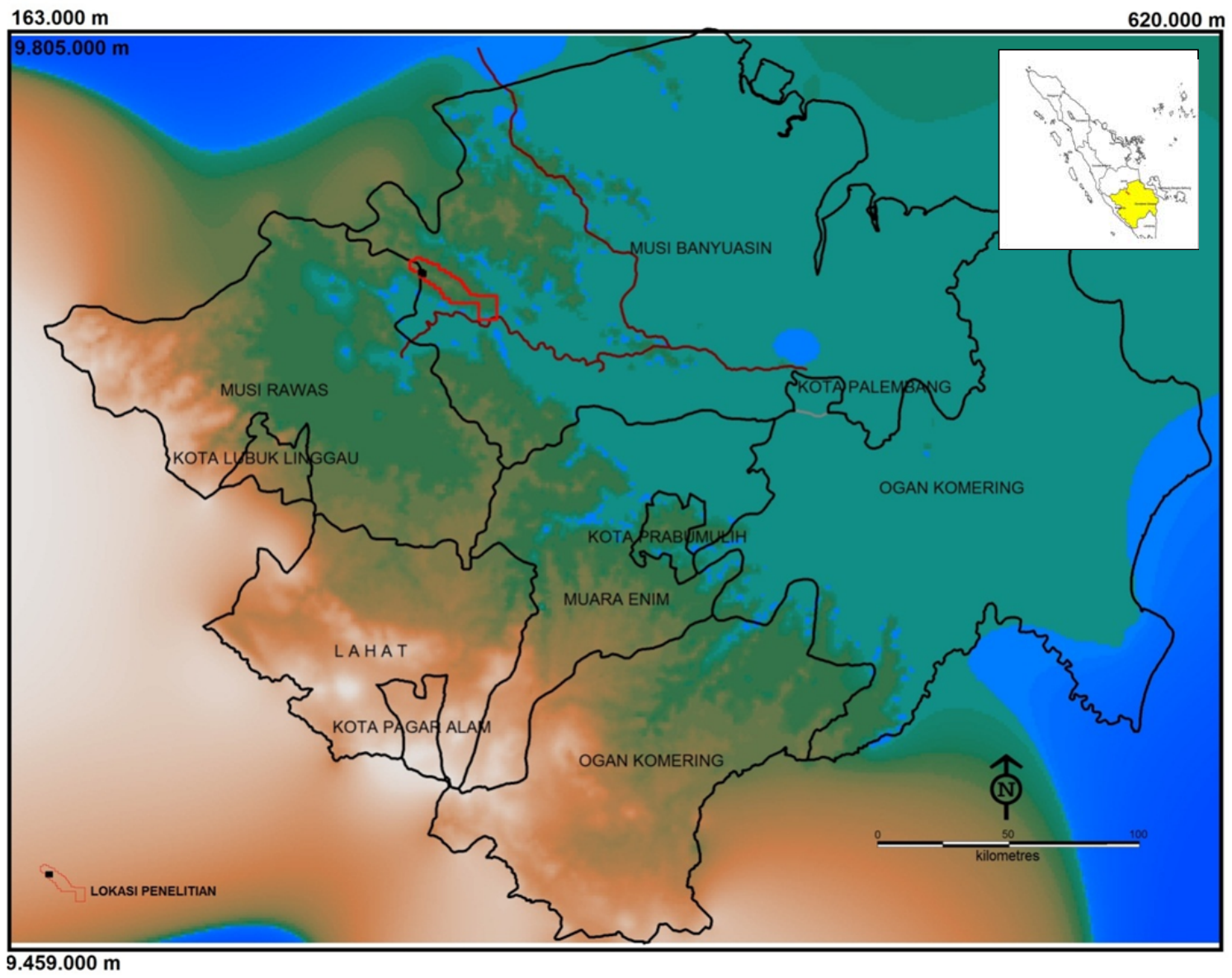

Gambar 1. Lokasi penelitian di daerah Macang Sakti, Musi Banyuasin, Sumatera Selatan. 
- Sumber daya terukur, yaitu bagian dari total estimasi sumber daya batubara yang kualitas dan kuantitasnya dapat diperkirakan dengan tingkat kepercayaan yang tinggi, didasarkan pada informasi yang didapat dari titik-titik pengamatan yang diperkuat dengan data pendukung. Titiktitik pengamatan jaraknya cukup berdekatan untuk membuktikan kemenerusan lapisan batubara dan/atau kualitasnya

Jarak titik informasi berdasarkan kondisi geologi sebagai dasar perhitungan sumber daya dapat dilihat pada Tabel 1 .

\section{KONDISI GEOLOGI}

Cekungan Sumatera Selatan merupakan salah satu cekungan yang penting dalam keterdapatan minyak dan gas bumi serta batubara (Amijaya and Littke, 2006; Susilawati and Ward, 2006; Daulay dan Santoso, 2008; Sosrowidjojo dan Saghafi, 2009; Badan Geologi, 2009; Susilawati dkk., 2015; (Friederich dkk., 2016). Direktorat Jenderal Minerba dan Batubara (2015) menyatakan bahwa Cekungan Sumatera Selatan ini menyumbangkan sepertiga sumber daya batubara di Indonesia.

Cekungan Sumatra Selatan mengalami tiga kali orogenesis, yakni pada Zaman Mesozoikum Tengah, Kapur Akhir-Tersier Awal, dan PlioPlistosen. Di dalam cekungan ini dikenal dua fase pengendapan, yaitu transgresif dan regresif. Fase transgresif menghasilkan endapan Kelompok Telisa yang terdiri atas Formasiformasi: Lahat, Talangakar, Baturaja dan Gumai. Sementara itu, fase regresif menghasilkan Formasi-formasi: Air Benakat, Muara Enim dan Kasai.

Hasil penelitian Amijaya dan Littke (2006), Susilawati dan Ward (2006), Daulay dan Santoso (2008) dan Sosrowidjojo dan Saghafi (2009) terhadap siklus pengendapan di cekungan ini menyimpulkan bahwa batuan dan endapan batubara yang termasuk ke dalam Formasi Muara Enim memiliki siklus pengendapan regresif. Orogenesis PlioPlistosen mengakhiri pengendapan dalam cekungan ini dan menghasilkan ketidakselarasan bersudut antara endapan Tersier dan endapan Kuarter di atasnya. Orogenesis ini diikuti oleh terobosan-terobosan andesit yang ternyata berpengaruh sangat penting dalam menaikkan kualitas batubara di Bukit Asam.

Cekungan ini berada pada suatu daerah tektonik aktif, sehingga lapisan pembawa batubara pada umumnya dipengaruhi oleh pelipatan, patahan, dan aktivitas intrusif dan ekstrusif. Adanya pengaruh intrusif ini mengakibatkan terjadinya pengangkatan, lipatan dan patahan. Akibatnya, setempatsetempat dijumpai rentang peringkat batubara mulai dari lignit sampai dengan antrasit.

Cekungan ini menghasilkan endapan batubara dengan penyebaran yang cukup luas, namun memiliki peringkat batubara tidak terlalu tinggi, kecuali di sekitar daerah intrusi andesit, seperti yang terdapat di lapangan batubara Air Laya, Suban, dan Bukit Kendi.

Selain Formasi Muara Enim juga terdapat lapisan-lapisan tipis batubara pada Formasi Talang Akar dan Formasi Lahat yang berumur relatif lebih tua dari pada Formasi Muara Enim. Juga diperkirakan terdapat potensi batubara berupa lapisan-lapisan tipis yang merupakan anggota Formasi Kasai yang berumur lebih muda daripada Formasi Muara Enim. Di dalam Formasi Muara Enim terdapat paling tidak 11 lapisan batubara utama, dari bawah ke atas: lapisan batubara Kladi, Merapi, Petai (C), Suban (B), Mangus (A), Burung, Benuang, Kebon, Benakat/Jelawatan, Lematang, Niru. Pengendapan batubara di formasi ini dipengaruhi saat susut laut pada peristiwa perubahan muka air laut yang terjadi pada Kala Miosen. Berdasarkan fasiesnya, Formasi Muara Enim dibagi menjadi 4 unit (Gambar 2), yaitu:

- Unit M1, merupakan bagian paling bawah dari batubara Formasi Muara Enim dibatasi bagian bawahnya oleh lapisan batubara Kladi dan Petai di bagian paling atas, dengan ketebalan keseluruhan 170-210m, terdiri atas batupasir halus berwarna abuabu terang, lanau-batupasir lanauan berwarna abu-abu, batupasir masif abu-abu kebiruan, batupasir halus berwarna abuabu, dan lanau abu-abu gelap. Banyak juga ditemukan lensa-lensa napal dalam runutan batuan, serta didapatkan 2 lapisan batubara dalam unit ini, yang berkembang secara tidak teratur, yaitu lapisan Merapi dan Kladi dengan ketebalan berkisar 1-8 m. 
Tabel 1. Jarak titik informasi berdasarkan kondisi geologi (BSN, 2011)

\begin{tabular}{|c|c|c|c|c|}
\hline \multirow{2}{*}{ Kondisi Geologi } & \multirow{2}{*}{ Kriteria } & \multicolumn{3}{|c|}{ Sumber daya } \\
\hline & & Tereka & Terunjuk & Terukur \\
\hline Sederhana & Jarak titik informasi (m) & $1000<x \leq 1500$ & $500<x \leq 1000$ & $X \leq 500$ \\
\hline Moderat & Jarak titik informasi (m) & $500<x \leq 1000$ & $250<x \leq 500$ & $X \leq 250$ \\
\hline Kompleks & Jarak titik informasi (m) & $200<x \leq 400$ & $100<x \leq 200$ & $X \leq 100$ \\
\hline
\end{tabular}

- Unit M2, pada runtunan batuan unit ini dijumpai 3 lapisan batubara, yaitu Petai, Suban dan Mangus. Lapisan Mangus ini berada di bagian atas unit M2 dan berbatasan dengan unit M3 di atasnya, dicirikan oleh sisipan batulempung tufaan dengan kandungan biotit, sedang batas bawahnya adalah lapisan Petai. Litologinya terdiri atas perselingan batulanau berwarna keabu-abuan, laminasi batulanau berwarna abu-abu gelap, dan sisipan tipis batubara, mengandung sedikit napal sideritik, setempat lapisan batubara mengalami pencabangan.

- Unit M3, terdapat 2 lapisan utama, yaitu Lapisan Burung dan Lapisan Binuang. Batas atas adalah Lapisan Kebon (Unit M4) dan batas bawah adalah Lapisan Mangus (Unit M2). Litologi terdiri atas batupasir halus sampai kasar berwarna abu-abu keputihan dan bersifat tufaan, berselingan dengan batulanau abu-abu, batulempung dan sisipan batubara, penyebaran batubara secara lateral umumnya buruk.

- Unit M4, adalah runtunan batuan di antara bagian bawah Lapisan Enim dan dasar dari Formasi Kasai, dengan total ketebalan berkisar 124-185 m. Lapisan batubara Enim memiliki ketebalan sekitar $10-20 \mathrm{~m}$ dan memiliki penyebaran yang luas. Lapisan batubara ini umumnya berupa satu lapisan dengan pengotoran bercirikan adanya fragmen resin yang cukup banyak. Lapisan antara Enim dan Jelawatan umumnya terdiri atas perselingan batupasir abu-abu terang dan batulanau yang berwarna abu-abu gelap sampai abu-abu, dengan sebagian berupa materi tufaan dan 3-5 lapisan batubara dengan ketebalan kurang dari $3 \mathrm{~m}$, setempat dengan penerusan lapisan yang buruk.

Lingkungan pengendapan batubara Formasi Muara Enim berada di cekungan busur belakang yang mempunyai ciri penyebaran batubara yang luas dengan ketebalan batubara bervariasi (Amijaya dan Littke (2006), Susilawati dan Ward (2006), Daulay dan Santoso (2008), Sosrowidjojo dan Saghafi (2009), dan Susilawati dkk. (2015)).

\section{HASIL DAN PEMBAHASAN}

\section{Pemodelan Endapan Batubara}

Pembuatan model stratigrafi merupakan proses berkelanjutan, jika satu langkah telah selesai, maka akan dilanjutkan ke langkah berikutnya. Oleh karena itu, diperlukan suatu persiapan agar proses berjalan dengan lancar. Data yang diperlukan adalah, data kolar (collar) titik bor dan data litologi batubara yang meliputi: kode lubang bor, kedalaman lubang bor, koordinat lubang bor $(x, y, z)$, interval kedalaman batubara (Tabel 2). Kemudian, menginterpretasi penamaan lapisan batubara dengan memperhatikan kesamaan ciri fisik (ketebalan dan penampakan). Penamaan sangat baik, jika didukung dengan data hasil logging geofisika (Gambar 3). Kemudian data litologi batubara dikorelasikan antar titik bor, sehingga menghasilkan gambaran penyebaran lapisan batubara di bawah permukaan bumi (Darmawan, 2012). Dari hasil korelasi lapisan batubara $\mathrm{D}$ antar titik bor, dihasilkan gambar penampang pada Gambar-gambar 4, 5 dan 6. 
Tabel 2. Data kolar lapisan batubara D

\begin{tabular}{|c|c|c|c|c|c|c|c|c|c|c|}
\hline \multirow[b]{2}{*}{ Hole_id } & \multirow{2}{*}{$\frac{\text { Easting }}{\mathrm{X}}$} & \multirow{2}{*}{$\frac{\text { Northing }}{\mathrm{Y}}$} & \multirow{2}{*}{$\begin{array}{c}\text { Elevasi } \\
\text { Permukaan titik } \\
\text { bor } \mathrm{m}(\mathrm{dpl})\end{array}$} & \multirow{2}{*}{$\begin{array}{c}\text { Depth } \\
\text { pemboran } \\
(\mathrm{m})\end{array}$} & \multirow[b]{2}{*}{ Seam } & \multicolumn{4}{|c|}{ Elevasi batubara } & \multirow{2}{*}{$\begin{array}{c}\text { Tebal } \\
\text { batubara }\end{array}$} \\
\hline & & & & & & $\begin{array}{c}\text { From } \\
(\mathrm{m})\end{array}$ & To $(\mathrm{m})$ & $\begin{array}{c}\text { Roof } \\
\text { (mdpl) }\end{array}$ & $\begin{array}{l}\text { Floor } \\
\text { (mdpl) }\end{array}$ & \\
\hline UCG-01 & $319,095.8$ & $9,714,237.1$ & 76.45 & 256.00 & $\mathrm{D}$ & 253.20 & 244.30 & -158.75 & $\begin{array}{l}-167.85 \\
\end{array}$ & 9.10 \\
\hline UCG-02 (01) & $319,080.8$ & $9,714,144.2$ & 75.30 & 293.00 & D & 268.83 & 278.30 & -193.53 & -203.00 & 9.47 \\
\hline UCG-03 & $319,042.8$ & $9,714,105.9$ & 72.34 & 313.50 & D & 292.40 & 301.00 & -220.06 & -228.66 & 8.60 \\
\hline UCG-04 & $319,289.4$ & $9,714,137.2$ & 75.85 & 238.00 & $\mathrm{D}$ & 215.10 & 224.17 & -139.25 & -148.22 & 9.07 \\
\hline UCG-05 (02A) & $319,248.0$ & $9,714,097.7$ & 75.10 & 258.55 & D & 239.22 & 248.40 & -164.12 & -173.30 & 9.18 \\
\hline UCG-06 (02) & $319,250.3$ & $9,714,040.9$ & 78.25 & 283.05 & $\mathrm{D}$ & 264.13 & 273.40 & -185.88 & -195.15 & 9.27 \\
\hline UCG-07 & $319,548.9$ & $9,714,018.7$ & 67.50 & 275.15 & D & 260.00 & 268.10 & -192.50 & -200.60 & 8.10 \\
\hline UCG-09 & $319,682.9$ & $9,713,794.8$ & 72.30 & 290.15 & D & 249.3 & 260 & -177.00 & -187.70 & 10.70 \\
\hline UCG-10 & $319,666.5$ & $9,713,737.8$ & 71.00 & 301.00 & D & 279.2 & 288 & -208.20 & -217.00 & 8.80 \\
\hline UCG-11 & $319,703.1$ & $9,713,698.1$ & 71.00 & 311.00 & D & 285.3 & 294.4 & -214.30 & -223.40 & 9.10 \\
\hline UCG-12 & $319,843.3$ & $9,713,569.7$ & 64.30 & 289.20 & D & 279.15 & 287.73 & -214.85 & -223.43 & 8.58 \\
\hline
\end{tabular}

\section{GEOLOGI REGIONAL}

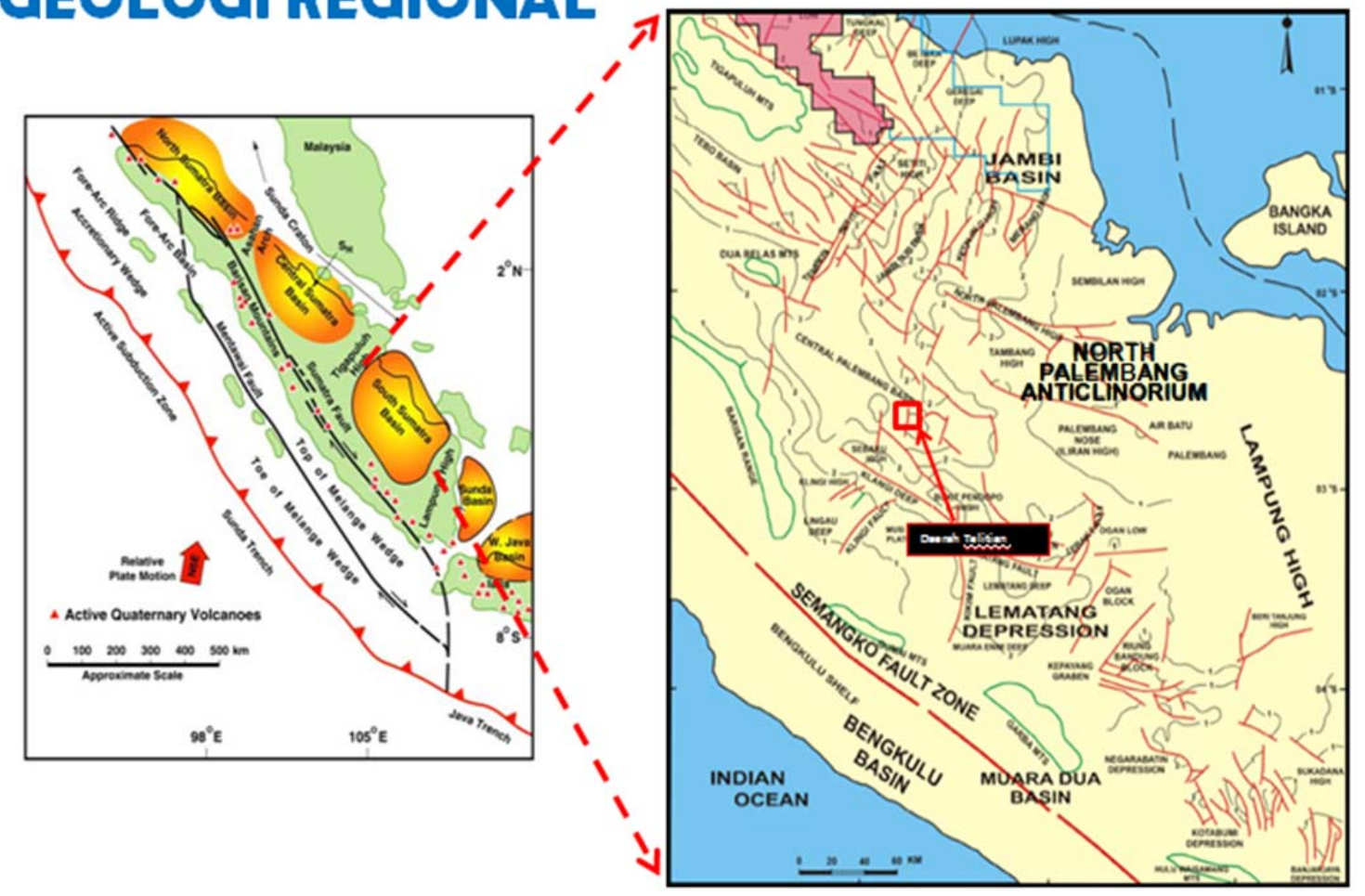

Gambar 2a. Peta Geologi Regional daerah penelitian (Gafoer $d k k ., 2007$ ) 


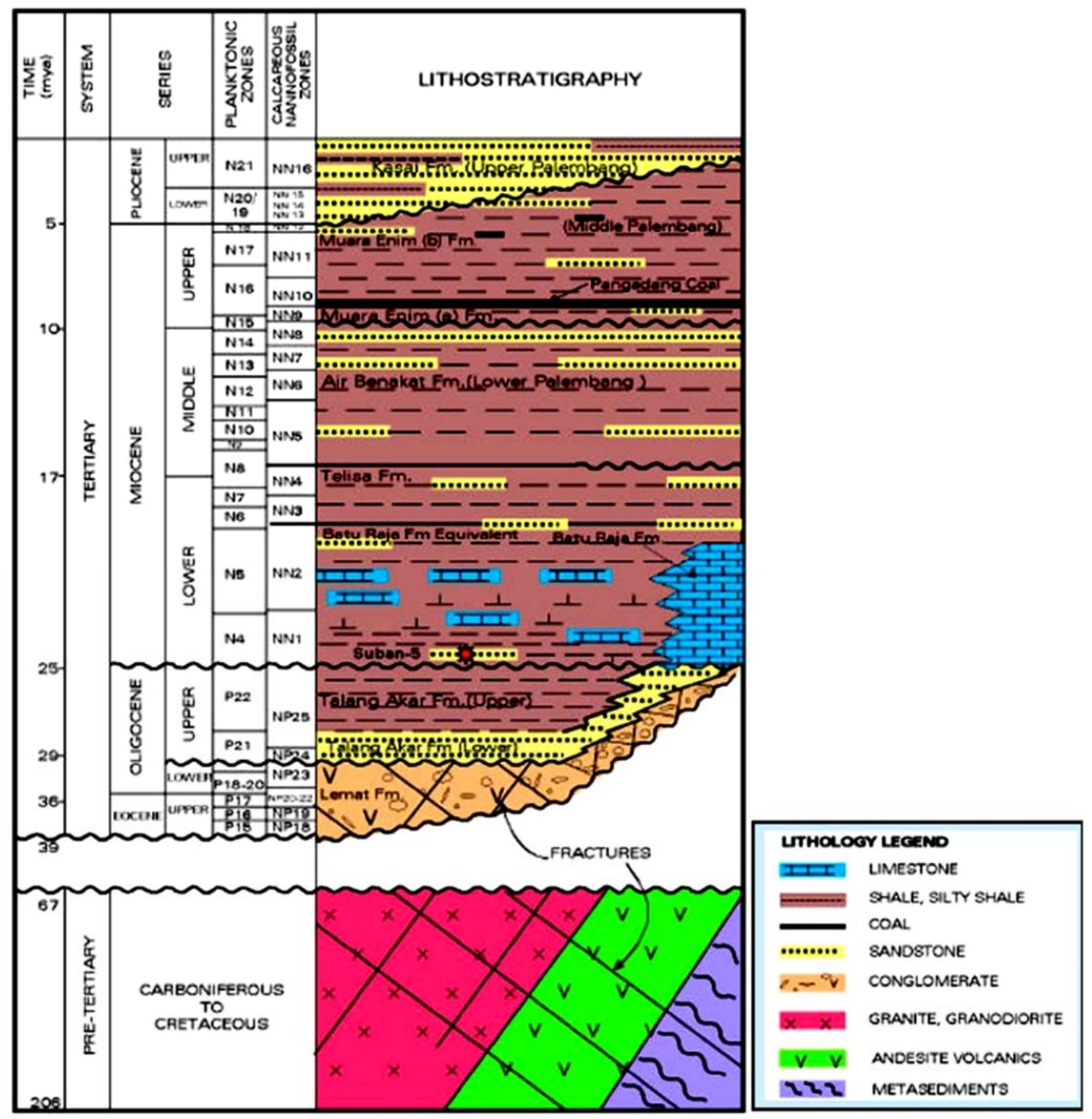

Gambar 2b. Kolom stratigrafi daerah penelitian 


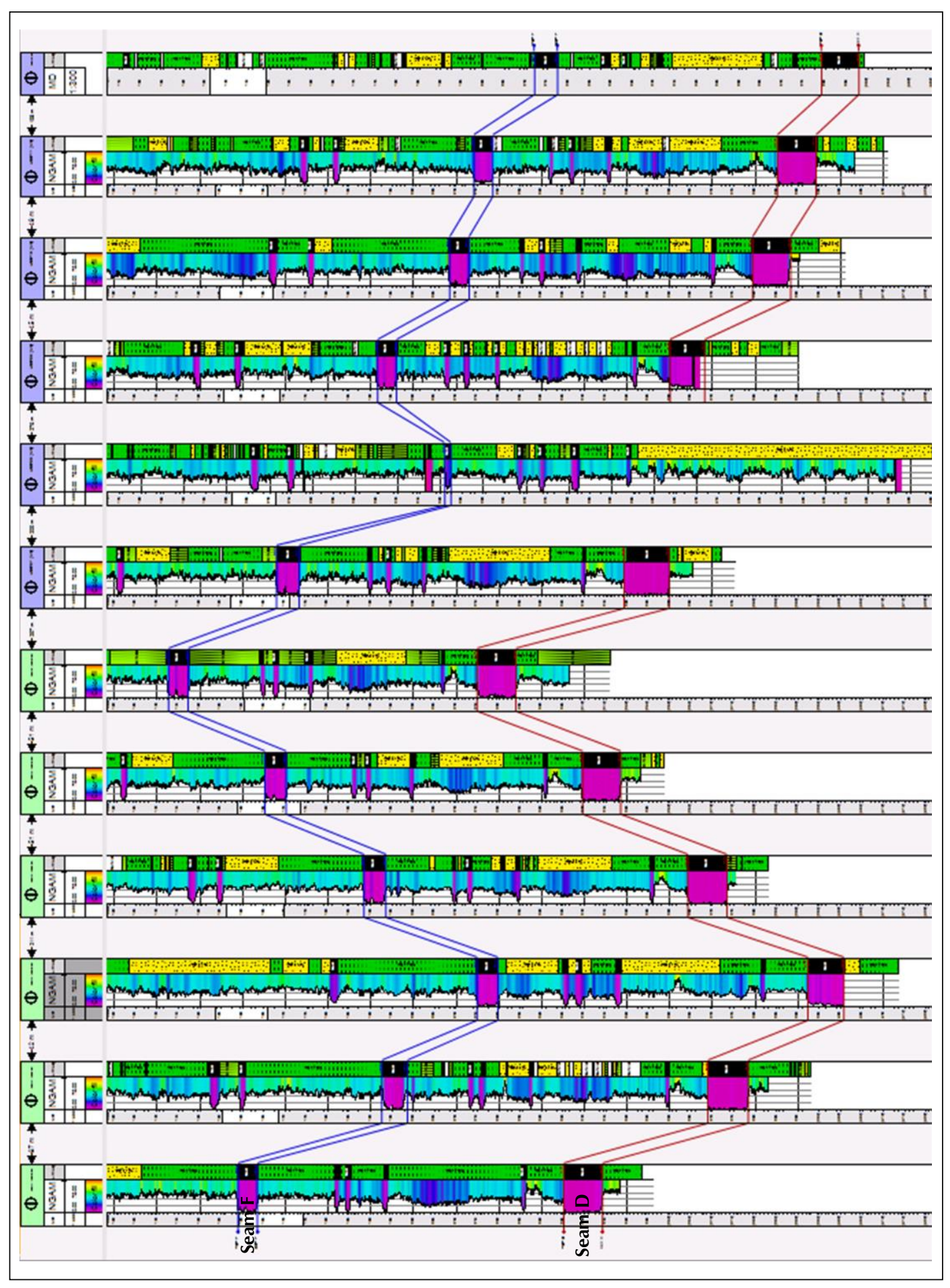




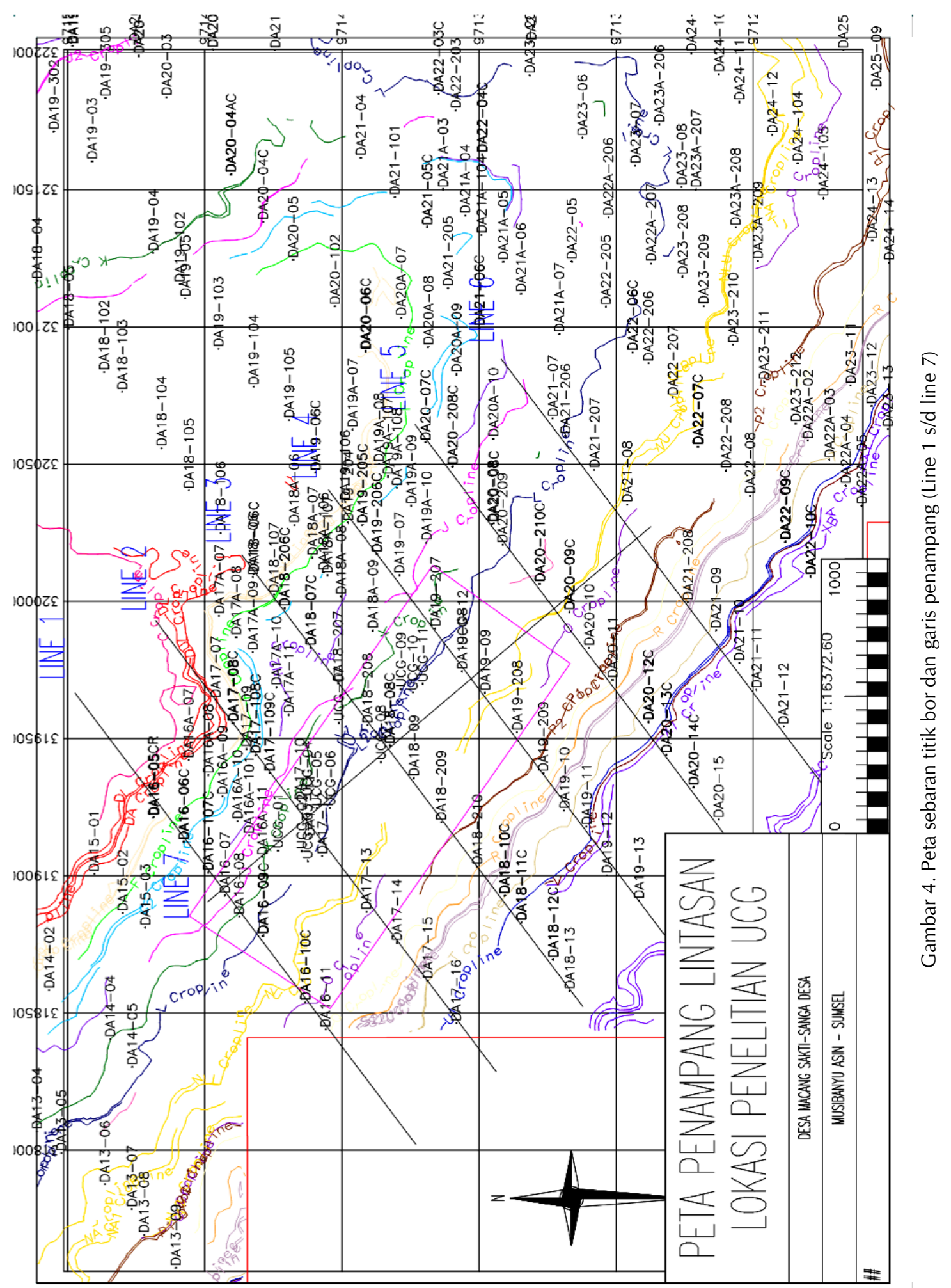




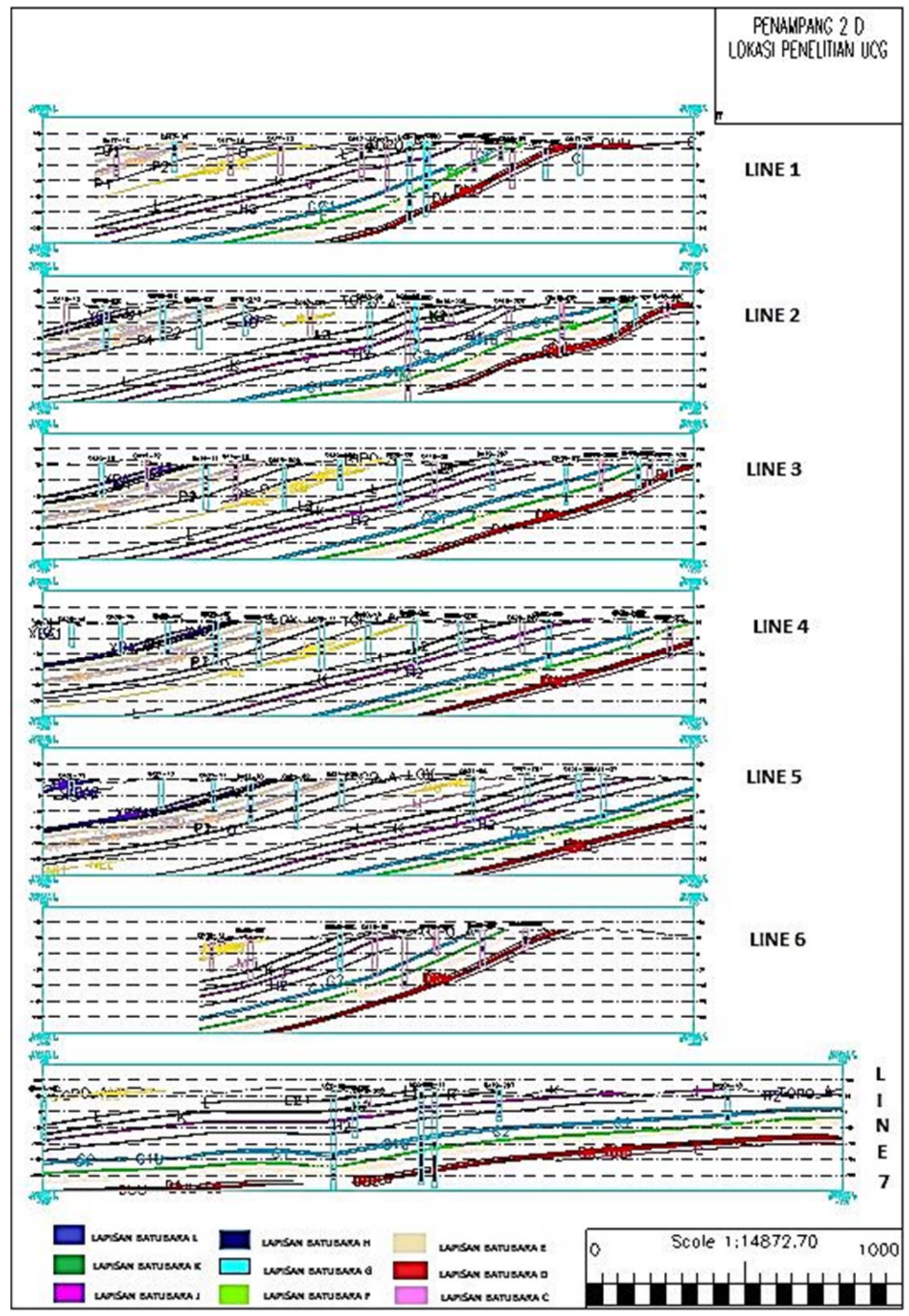

Gambar 5. Peta penampang 2D batubara 


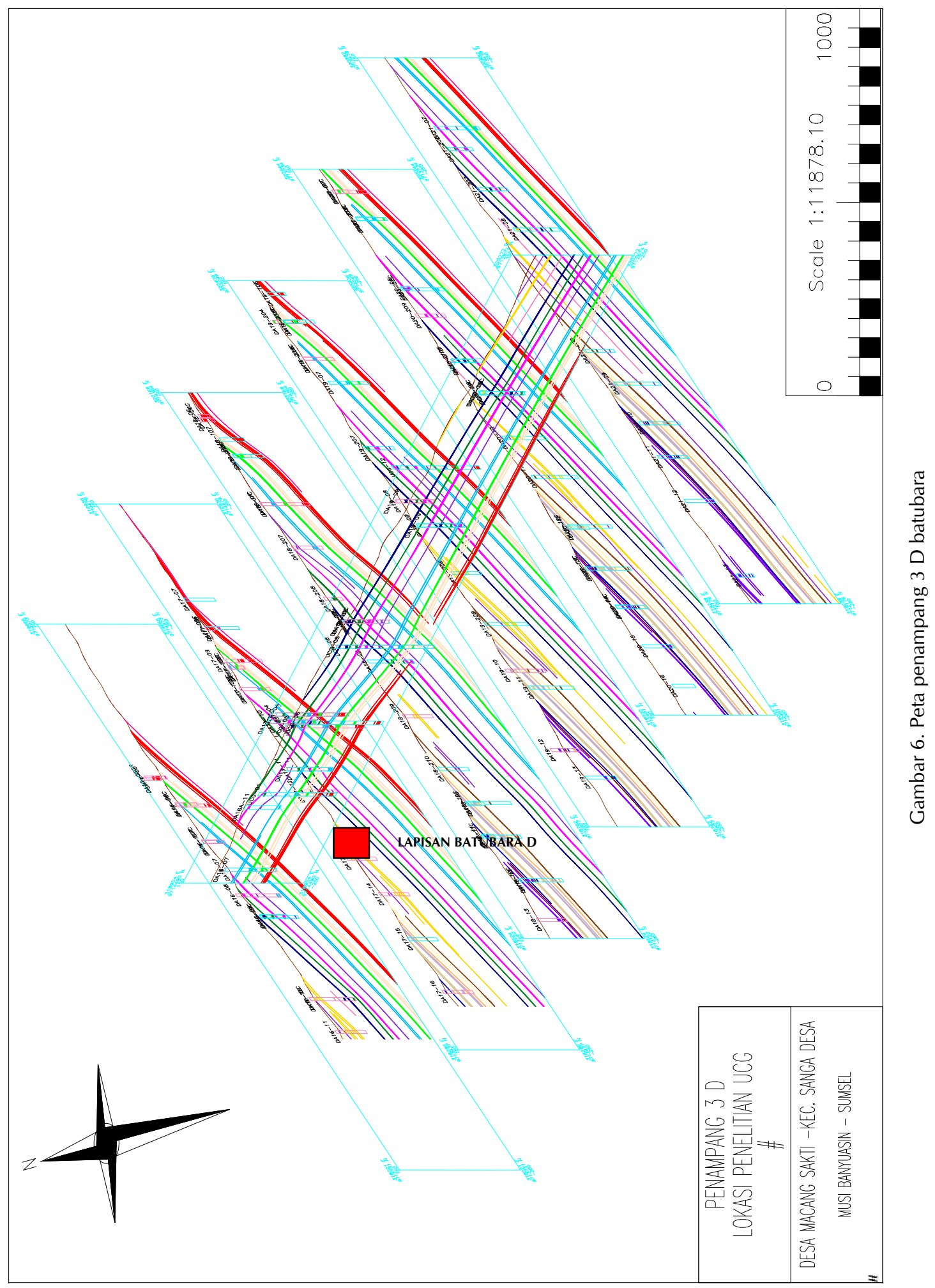




\section{Pembuatan Iso Kualitas}

Iso kualitas dibuat untuk mengetahui penyebaran kualitas batubara (Darmawan, 2012), yang dihasilkan dari pengujian kualitas batubara pada 7 titik bor pada lapisan batubara D. Dari data hasil uji kualitas lapisan batubara D, didapatkan bahwa Batubara lapisan D mempunyai nilai reflektansi vitrinit rata rata antara 0,23 s/d 0,44 (Tabel 3), dengan kondisi semakin ke bawah nilai reflektansi vitrinit relatif meningkat. Dari data tersebut dapat disimpulkan batubara lapisan D mempunyai rank (peringkat) kematangan batubara antara lignit $\mathrm{s} / \mathrm{d}$ subbituminus berdasarkan klasifikasi batubara Australian Standard 1986. Peta sebaran kesamaan nilai

Tabel 3. Hasil uji nilai reflektansi vitrinit

\begin{tabular}{cccc}
\hline \multirow{2}{*}{ Hole_id } & \multicolumn{3}{c}{ REFLEKTANSI VITRINIT } \\
\cline { 2 - 4 } & MAX & MIN & MEAN \\
\hline UCG-02 (01) & 0,32 & 0,24 & 0,27 \\
& 0,39 & 0,31 & 0,34 \\
& 0,41 & 0,31 & 0,36 \\
& & & 0,32 \\
\hline UCG-05 (02A) & 0,3 & 0,21 & 0,27 \\
& 0,36 & 0,27 & 0,33 \\
& 0,41 & 0,3 & 0,35 \\
& & & 0,317 \\
\hline UCG-06 (02) & 0,32 & 0,22 & 0,28 \\
& 0,29 & 0,2 & 0,23 \\
& 0,29 & 0,21 & 0,24 \\
& & & 0,25 \\
\hline UCG-07 & 0,44 & 0,33 & 0,39 \\
& 0,37 & 0,31 & 0,34 \\
& 0,3 & 0,22 & 0,26 \\
& 0,39 & 0,33 & 0,37 \\
& 0,39 & 0,32 & 0,35 \\
& 0,46 & 0,37 & 0,42 \\
& 0,46 & 0,37 & 0,41 \\
& 0,39 & 0,32 & 0,36 \\
& 0,41 & 0,31 & 0,35 \\
& & 0,361 \\
\hline
\end{tabular}

reflektan vitrinit/rank Batubara dapat dilihat pada Gambar 7b. Sedangkan dari data hasil uji nilai kalor (Tabel 4), batubara lapisan D mempunyai nilai kalor $4.912 \mathrm{Kkal} / \mathrm{kg}$ s/d $6.275 \mathrm{Kkal} / \mathrm{kg}$, peta sebaran nilai kalor dapat dilihat pada Gambar 7a. Dari data kadar air total (Tabel 4), batubara lapisan D mempunyai kadar air antara 29,19\% s/d 44,6\%. Dari data kadar abu (Tabel 4), batubara lapisan D mempunyai kadar abu $1,77 \% \mathrm{~s} / \mathrm{d} 4,88 \%$, peta sebaran dapat dilihat pada Gambar 8a dan 8b. Berdasarkan batasan batubara untuk UCG yang menyaratkan batubara lignit $\mathrm{s} / \mathrm{d}$ bituminus dan kadar air + kadar abu $<60 \%$, maka batubara lapisan D sudah memenuhi persyaratan sebagai batubara yang dapat dieksploitasi dengan metode UCG.

\begin{tabular}{|c|c|c|c|}
\hline \multirow{2}{*}{ Hole_id } & \multicolumn{3}{|c|}{ REFLEKTANSI VITRINIT } \\
\hline & MAX & MIN & MEAN \\
\hline \multirow{7}{*}{ UCG-09 } & 0,41 & 0,32 & 0,37 \\
\hline & 0,41 & 0,3 & 0,35 \\
\hline & 0,43 & 0,33 & 0,38 \\
\hline & 0,34 & 0,27 & 0,3 \\
\hline & 0,4 & 0,32 & 0,35 \\
\hline & 0,38 & 0,3 & 0,34 \\
\hline & & & 0,348 \\
\hline \multirow[t]{7}{*}{ UCG-11 } & 0,39 & 0,31 & 0,35 \\
\hline & 0,39 & 0,3 & 0,34 \\
\hline & 0,38 & 0,3 & 0,34 \\
\hline & 0,43 & 0,36 & 0,39 \\
\hline & 0,42 & 0,37 & 0,4 \\
\hline & 0,49 & 0,38 & 0,43 \\
\hline & & & 0,38 \\
\hline \multirow[t]{7}{*}{ UCG-12 } & 0,41 & 0,26 & 0,39 \\
\hline & 0,39 & 0,3 & 0,34 \\
\hline & 0,4 & 0,31 & 0,36 \\
\hline & 0,45 & 0,35 & 0,4 \\
\hline & 0,46 & 0,41 & 0,44 \\
\hline & 0,39 & 0,3 & 0,35 \\
\hline & & & 0,38 \\
\hline
\end{tabular}


Tabel 4. Hasil uji kualitas proksimat

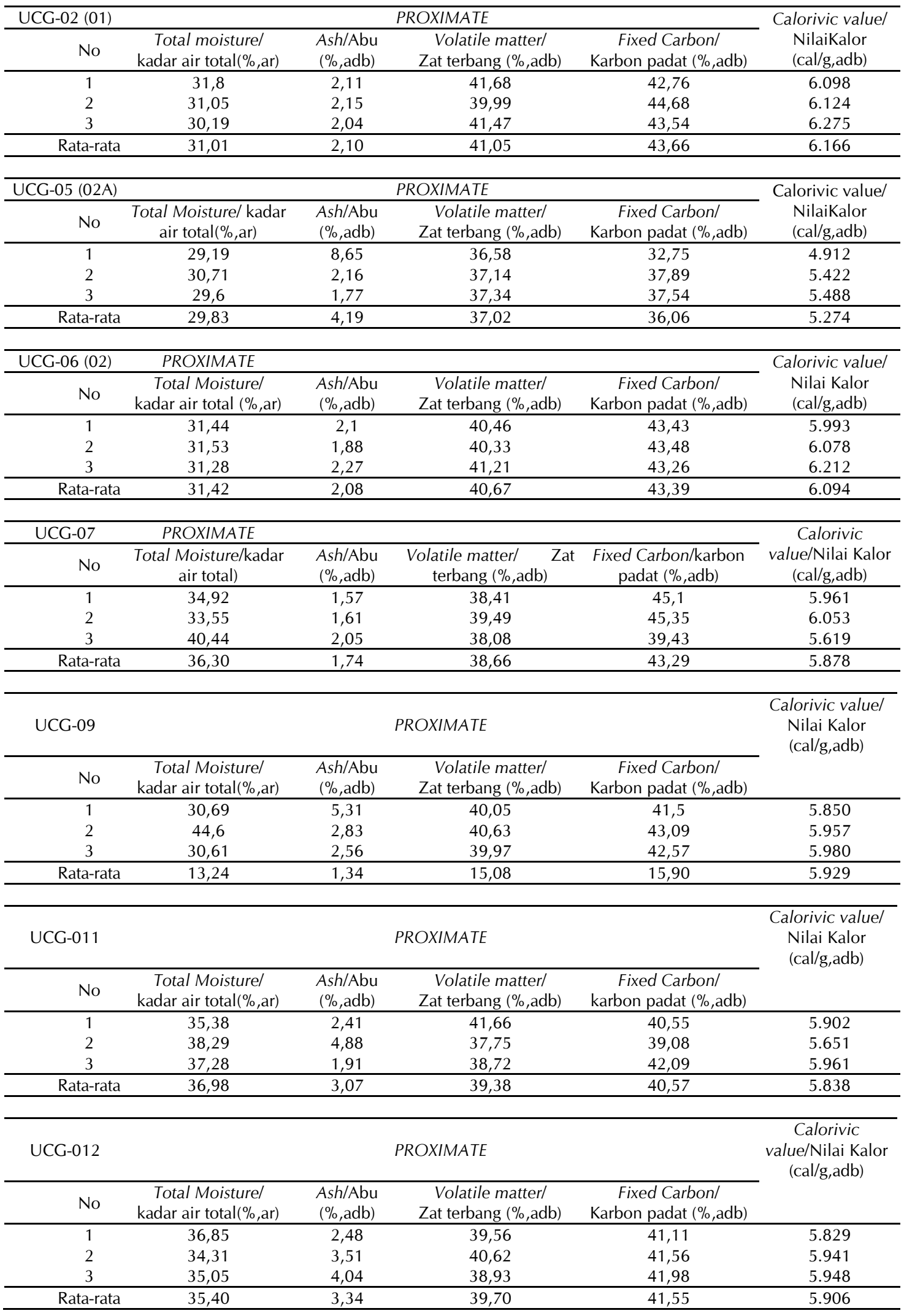




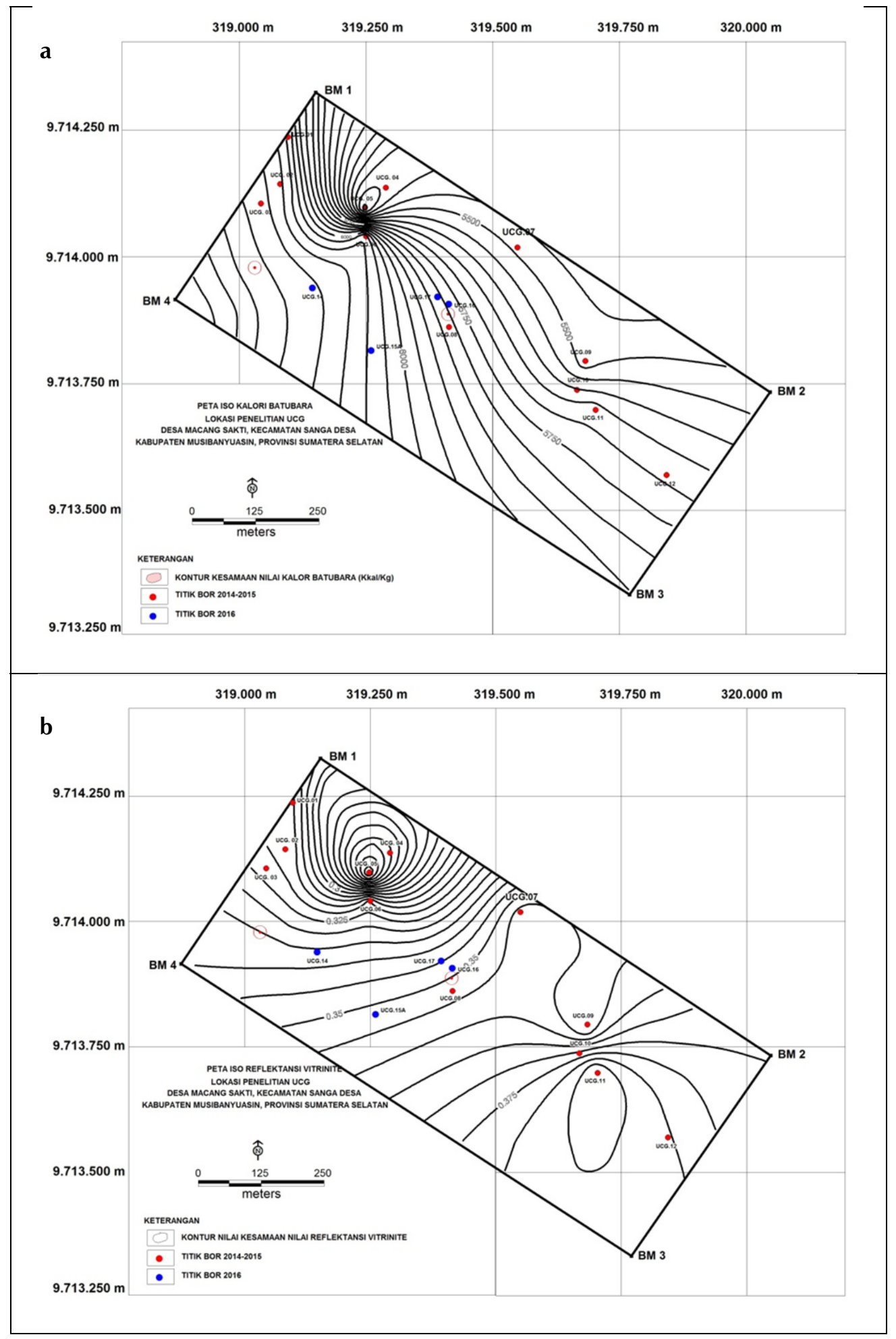

Gambar 7. a. Peta iso nilai kalori dan b. Peta iso reflektansi vitrinit 
Potensi Batubara untuk Pengembangan Gasifikasi Bawah Permukaan ... Asep B. Purnama dkk.

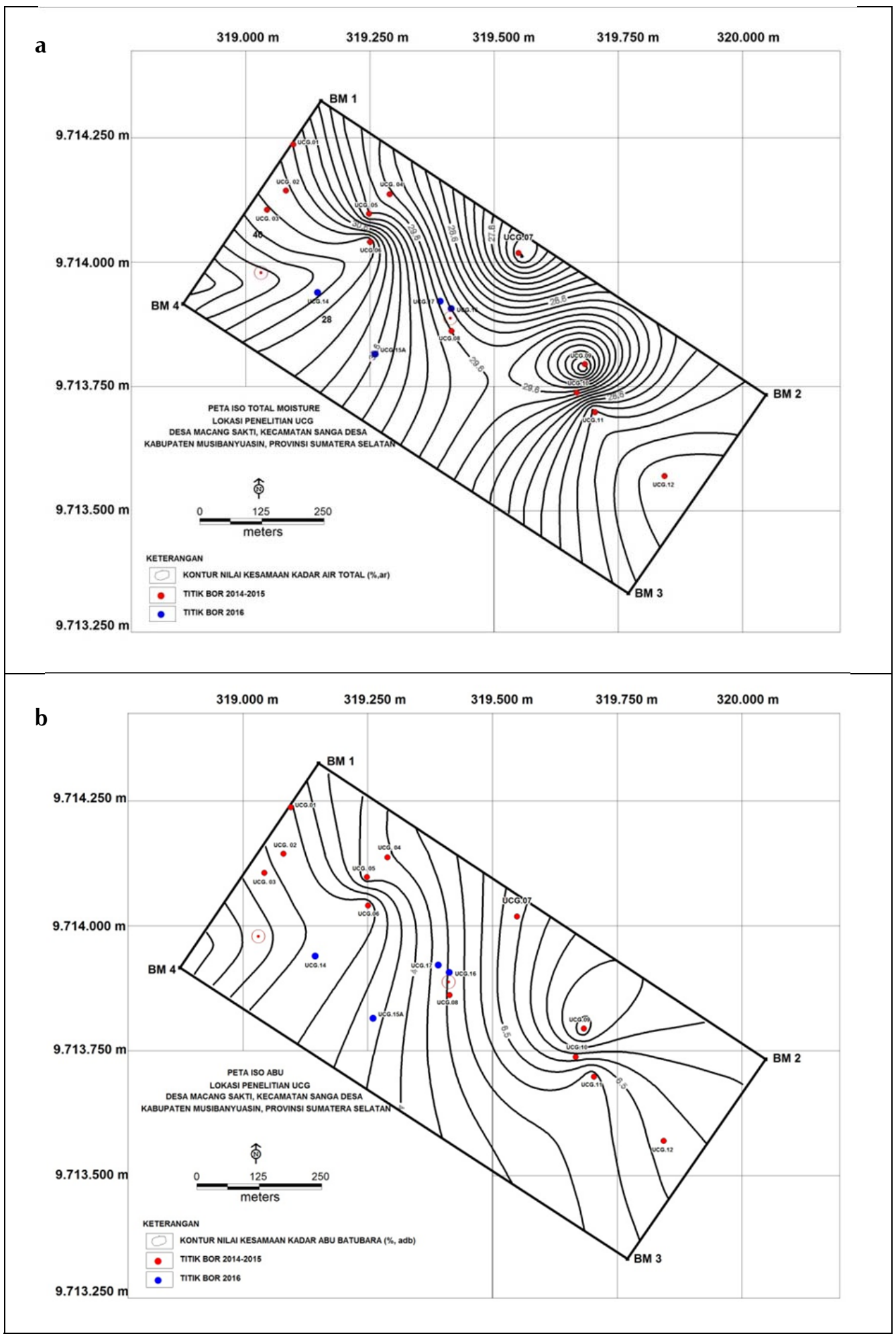

Gambar 8. a. Peta iso kadar air total dan b. Peta iso kadar Abu 


\section{Pemodelan dan Perhitungan Sumber Daya Batubara UCG}

Batubara yang dimodelkan dan dihitung adalah batubara yang memenuhi syarat untuk dapat dieksploitasi dengan metode UCG, yaitu memiliki ketebalan $>5 \mathrm{~m}$ dan kedalaman batubara antara 200-300 m, berperingkat lignit-subbituminus dan jumlah kadar air lembab dan kadar abu $<60 \%$ (Khadse dkk., 2007; Friedmann dkk., 2009; Kreynin, 2012; Bhutto $d k k_{.}, 2013$; Imran dkk., 2014; Santoso, 2015).

Dari hasil pemodelan didapatkan bahwa lapisan batubara D relatif menerus dengan ketebalan relatif konstan, terkecuali pada satu titik pengeboran di UCG-08 lapisan batubara D menghilang (tidak menerus), area ini akan dihindari untuk pengembangan UCG (Gambar 9). Dari sisi kualitas, lapisan batubara ini termasuk ke dalam subbituminus dengan nilai kalori $4.912 \mathrm{~s} / \mathrm{d} 6.275 \mathrm{kkal} / \mathrm{kg}$, dengan kadar air total + kadar abu $<60 \%$. Dengan demikian, lapisan batubara ini sudah memenuhi syarat untuk dijadikan batubara UCG (Khadse $d k k$., 2007; Friedmann $d k k .$, 2009; Kreynin, 2012; Bhutto $d k k .$, 2013; Imran $d k k ., 2014$; Santoso, 2015).

Berdasarkan BSN (2011), kondisi geologis di lokasi batubara ini dianggap moderat, sehingga area pengaruh batubara mengikuti kondisi geologi moderat, dengan area pengaruh untuk sumber daya terukur $250 \mathrm{~m}$, sumber daya tertunjuk 250-500 m dan sumber daya tereka 500-1000 m. Setelah dikompilasi dengan kontur kedalaman 200-300 m, didapatkan deliniasi area sumber daya lapisan batubara D, dengan jumlah sumber daya terukur berjumlah 3.446.166 $\mathrm{m}^{3}$, sumber daya tertunjuk 1.468.892,6 $\mathrm{m}^{3}$, dan sumber daya tereka 2.551.214 $\mathrm{m}^{3}$. Dengan hasil uji densitas batubara sebesar 1.29, maka batubara tersebut dikonversi ke tonase dengan mengalikan faktor densitas sebesar 1.29, sehingga mendapatkan lapisan batubara D menjadi sumber daya terukur sebesar 4.479.951 ton, sumber daya tertunjuk sebesar 1.909.560 ton, dan sumber daya tereka sebesar 3.316.578 ton.

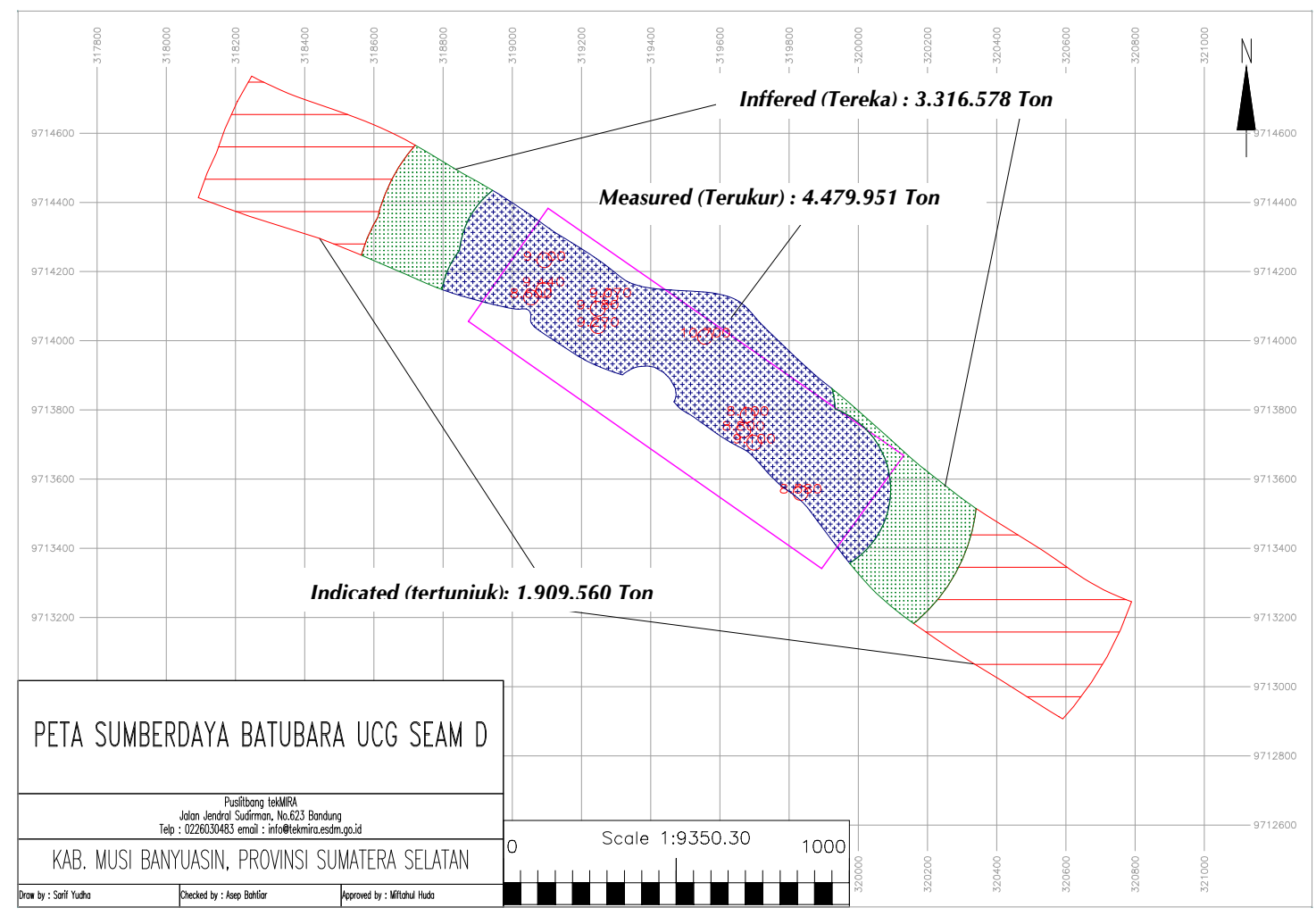

Gambar 9. Peta perhitungan sumber daya lapisan batubara D 


\section{KESIMPULAN}

Sumber daya batubara Formasi Muara Enim Cekungan Sumatera Selatan memiliki peluang besar untuk dimanfaatkan sebagai daerah kegiatan untuk penelitian UCG. Sumber daya batubara di cekungan ini relatif besar, sehingga terpilih menjadi lokasi penelitian yang dilakukan oleh Tim UCG Pusat Penelitian dan Pengembangan Teknologi Mineral dan Batubara. Berdasarkan kegiatan pengeboran batubara secara rinci yang telah dilakukan, didapatkan sumber daya batubara lapisan D sebagai berikut; sumber daya terukur sebesar 4.479.951 ton, sumber daya tertunjuk sebesar 1.909 .560 ton, serta sumber daya tereka sebesar 3.316 .578 ton dan memenuhi aspek parameter ketebalan lebih dari $5 \mathrm{~m}$ yaitu $9 \mathrm{~m}$ dengan kedalaman berada di antara $200 \mathrm{~m}$ s/d $300 \mathrm{~m}$. Kualitas batubara lapisan D ini termasuk ke dalam lignit s/d subbituminus dangan nilai kalori 4.912 s/d $6.275 \mathrm{kkal} / \mathrm{kg}$, kandungan kadar air total + kadar abu $<60 \%$. Dengan demikian, lapisan batubara ini sudah memenuhi syarat untuk dijadikan batubara UCG.

\section{UCAPAN TERIMA KASIH}

Penulis mengucapkan terima kasih kepada Kepala Pusat Penelitian dan Pengembangan Teknologi Mineral dan Batubara yang telah memberikan dukungan penuh atas terlaksananya kegiatan kelitbangan UCG ini. Ucapan terima kasih juga penulis tujukan kepada rekan-rekan di laboratorium batubara yang telah membantu menganalisis batubara secara cermat. Kepada para pembantu kegiatan kelitbangan di lokasi penelitian, penulis juga mengucapkan terima kasih atas usahanya dalam menyelesaikan kegiatan ini.

\section{DAFTAR PUSTAKA}

Amijaya, H. dan Littke, R. (2006) "Properties of thermally metamorphosed coal from Tanjung Enim Area, South Sumatra Basin, Indonesia with special reference to the coalification path of macerals," International Journal of Coal Geology, 66(4), hal. 271-295. doi: 10.1016/j.coal.2005.07.008.

Australian Standard (1986) Coal maceral analysis. North Sidney.
Badan Geologi (2009) Peta cekungan sedimen Indonesia berdasarkan data gaya berat dan geologi skala 1:5.000.000. Bandung.

Badan Geologi (2014) Pemutakhiran data sumber daya energi status 2014.

Badan Standardisasi Nasional (2011) SNI 50152011: Pedoman pelaporan sumber daya dan cadangan batubara. Jakarta.

Bhutto, A. W., Bazmi, A. A. dan Zahedi, G. (2013) "Underground coal gasification: From fundamentals to applications," Progress in Energy and Combustion Science, hal. 189214. doi: 10.1016/j.pecs.2012.09.004.

Bielowicz, B. dan Kasiński, J. R. (2014) “The possibility of underground gasification of lignite from Polish deposits," International Journal of Coal Geology, 131, hal. 304-318. doi: 10.1016/j.coal.2014.06.025.

Darmawan, J. (2012) "Pemodelan geologi batubara daerah Marangkayu, Kabupaten Kutai Kertanegara, menggunakan coal resources and reserves evaluation system," Buletin Sumber Daya Geologi, 7, hal. 57-66.

Daulay, B. dan Santoso, B. (2008) "Characteristics of selected Sumateran tertiary coals regarding their petrographic analyses," Indonesian Mining Journal, 11(10), hal. 1-18.

Fatimah, Suryana, A. dan Wibisono, S. A. (2014) "Potensi deep seated coal Indonesia," Mineral dan Energi, 12(2), hal. 18-28.

Friederich, M. C., Moore, T. A. dan Flores, R. M. (2016) "A regional review and new insights into SE Asian Cenozoic coal-bearing sediments: Why does Indonesia have such extensive coal deposits?," International Journal of Coal Geology, 166(1 September 2016), hal. 2-35. doi: 10.1016/j.coal.2016.06.013.

Friedmann, S. J., Upadhye, R. dan Kong, F.-M. (2009) "Prospects for underground coal gasification in carbon-constrained world," Energy Procedia, 1(1), hal. 4551-4557. doi: 10.1016/j.egypro.2009.02.274.

Gafoer, S., Amin, T. C. dan Purnomo, J. (2007) Peta geologi lembar Lahat, Sumatera Selatan, skala 1:250.000. Bandung.

Imran, M., Kumar, D., Kumar, N., Qayyum, A., Saeed, A. dan Bhatti, M. S. (2014) "Environmental concerns of underground coal gasification," Renewable and Sustainable 
Energy Reviews, 31(March 2014), hal. 600610. doi: 10.1016/j.rser.2013.12.024.

Kapusta, K., Stańczyk, K., Wiatowski, M. dan Chećko, J. (2013) "Environmental aspects of a field-scale underground coal gasification trial in a shallow coal seam at the Experimental Mine Barbara in Poland," Fuel, 113, hal. 196-208. doi: 10.1016/j.fuel.2013.05.015.

Khadse, A., Qayyumi, M., Mahajani, S. dan Aghalayam, P. (2007) "Underground coal gasification: A new clean coal utilization technique for India," Energy, 32(11), hal. 2061-2071. doi:

10.1016/j.energy.2007.04.012.

Kreynin, E. V. (2012) "An analysis of new generation coal gasification projects," International Journal of Mining Science and Technology, 22(4), hal. 509-515. doi: 10.1016/j.ijmst.2012.01.012.

Santoso, B. (2015) Petrologi batubara Sumatera dan Kalimantan: Jenis, peringkat dan aplikasi. 1 ed. Diedit oleh M. Kadapi dan $M$. Helmiawan. Jakarta: LIPI Press.

Sosrowidjojo, I. B. dan Saghafi, A. (2009) "Development of the first coal seam gas exploration program in Indonesia: Reservoir properties of the Muaraenim Formation, south Sumatra," International Journal of Coal Geology, 79(4), hal. 145-156. doi: 10.1016/j.coal.2009.07.002.

Susilawati, R., Evans, P. N., Esterle, J. S., Robbins, S. J., Tyson, G. W., Golding, S. D. dan Mares, T. E. (2015) "Temporal changes in microbial community composition during culture enrichment experiments with Indonesian coals," International Journal of Coal Geology, 137, hal. 66-76. doi: 10.1016/j.coal.2014.10.015.

Susilawati, R. dan Ward, C. R. (2006) "Metamorphism of mineral matter in coal from the Bukit Asam deposit, south Sumatra, Indonesia," International Journal of Coal Ceology, 68(3-4), hal. 171-195. doi: 10.1016/j.coal.2006.02.003.

Zieleniewski, M. dan Brent, A. C. (2008) "Evaluating the costs and achievable benefits of extending technologies for uneconomical coal resources in South Africa: the case of underground coal gasification," Journal of Energy in Southern Africa, 19(4), hal. 21-31. 